\title{
agriculture
}

ISSN 2077-0472

www.mdpi.com/journal/agriculture

Article

\section{Italian Wild Rocket [Diplotaxis Tenuifolia (L.) DC.]: Influence of Agricultural Practices on Antioxidant Molecules and on Cytotoxicity and Antiproliferative Effects}

\author{
Alessandra Durazzo ${ }^{1, *}$, Elena Azzini ${ }^{1}$, Maria Claudia Lazzè ${ }^{2}$, Anna Raguzzini ${ }^{1}$, \\ Roberto Pizzala $^{2}$ and Giuseppe Maiani ${ }^{1}$ \\ 1 Istituto Nazionale di Ricerca per gli Alimenti e la Nutrizione, Rome 00178, Italy; \\ E-Mails: azzini@inran.it (E.A.); raguzzini@inran.it (A.R.); maiani@inran.it (G.M.) \\ 2 Dipartimento di Medicina Molecolare, Unità di Immunologia e Patologia Generale, \\ Università degli Studi di Pavia, Pavia 27100, Italy; E-Mails: claudia.eugenio@virgilio.it (M.C.L.); \\ roberto.pizzala@unipv.it (R.P.) \\ * Author to whom correspondence should be addressed; E-Mail: durazzo@inran.it; \\ Tel.: +39-06-51494651; Fax: +39-06-51494550.
}

Received: 21 January 2013; in revised form: 16 April 2013 / Accepted: 22 April 2013 / Published: 6 May 2013

\begin{abstract}
Wild rocket [Diplotaxis tenuifolia (L.) DC.] belongs to the Brassicaceae family and has its origin in the Mediterranean region. The effect of conventional and integrated cultivation practices on the nutritional properties and benefits of wild rocket [Diplotaxis tenuifolia (L.) DC.] were studied. Bioactive molecules content (vitamin C, quercetin, lutein), antioxidant properties and bioactivity of polyphenolic extracts from the edible part of rocket in Caco-2 cells were determined. Regarding antioxidant properties, FRAP (Ferric Reducing Antioxidant Power) values ranged from $4.44 \pm 0.11 \mathrm{mmol} / \mathrm{kg}$ fw to $9.92 \pm 0.46$ $\mathrm{mmol} / \mathrm{kg}$ fw for conventional rocket and from $4.13 \pm 0.17 \mathrm{fw} \mathrm{mmol} / \mathrm{kg}$ to $11.02 \pm 0.45$ $\mathrm{mmol} / \mathrm{kg}$ fw for integrated rocket. The characteristics of wild rocket as a dietary source of antioxidants have been pointed out. Significant differences in the quality of conventional and integrated rocket have been shown, while no influence of agronomic practice on biological activity was reported. A significant accumulation of cells in G1 phase and a consequent reduction in the $\mathrm{S}$ and $\mathrm{G} 2+\mathrm{M}$ phases were observed in Caco-2 cells treated with rocket polyphenol extract.
\end{abstract}


Keywords: Italian wild rocket; agricultural practices; antioxidants; cytotoxicity; antiproliferative effects

\section{Introduction}

Rocket includes different species belonging to Eruca and Diplotaxis genera. Wild rocket [Diplotaxis tenuifolia (L.) DC.] belongs to the Brassicaceae family and has its origin in the Mediterranean region [1]. It is known for the pungent taste of its young leaves, which makes it appreciated for the salads and in cooked culinary preparations. Rocket has a long history of medicinal use for various purposes: antiphlogistic, astringent, depurative, diuretic, digestive, emollient, tonic, stimulant, laxative and rubefacient [2].

Rocket contains a range of health-promoting phytochemicals including carotenoids, vitamin $\mathrm{C}$, fiber, polyphenols and glucosinolates $[3,4]$. Glucosinolates represent the major class of compounds in rocket and their contents in this crop have been well documented in the literature $[5,6]$.

Several investigations have shown the potential role of phytochemicals in Brassicaceae in the prevention of certain diseases and types of cancer [7]; the health-promoting activities, including tumorogenesis inhibition and hepatoprotective effects, are attributed to rocket plants [8-10].

It is well known that the content of bioactive compounds — hence the nutritional quality of food — can be influenced by several factors such as genetics, degree of ripeness, agronomic and environmental conditions during growth, food preparation and processing.

Growing conditions include a large number of variable agronomic and environmental factors: climate, soil type, hours of sunlight, irrigation, nutrient supply, pest control, growing location, cultivation methods, time of harvest and others [11]. These variables can affect both crop productivity as well as the nutritional profile of plant.

Organic crop production systems are often contrasted to conventional crop production systems that typically rely on the application of broad-spectrum synthetic fertilizers and pesticides [12]. On a wide scale in Europe, so-called conventional methods have been replaced by an integrated farming system that reduces the use of synthetic chemicals by a combination of organic and conventional techniques [13]. The integrated farming system can be conceptualized as a "third way" or middle course for agriculture [14]. Few studies are reported in literature on how integrated agricultural systems affect the nutrient composition in plants $[15,16]$.

In this research the effects of conventional and integrated cultivation practices on the nutritional properties and benefits of wild rocket [Diplotaxis tenuifolia (L.) DC.] were studied.

In particular, we have studied antioxidant properties, bioactive molecules content (vitamin $\mathrm{C}$, quercetin, lutein) and the cytotoxicity and antiproliferative effects of polyphenolic extracts from the edible part of rocket in Caco- 2 cell models.

This paper describes changes in antioxidant composition of wild rocket in relationship to the agricultural practices utilized, assessing the optimal content of bioactive compounds and thus more healthful and nutritious food crops. 


\section{Results and Discussion}

\subsection{Bioactive Molecules and Antioxidant Properties}

In this agronomic investigation, we have studied the antioxidants content of wild rockets cultivated following a conventional and integrated system during two years of cultivation.

Table 1 shows the bioactive molecules content (quercetin, lutein, vitamin C) in wild rocket distributed by cultivation practice and year of cultivation.

Table 1. Bioactive molecules in rocket by agronomic practice and year of cultivation ${ }^{\Omega}$.

\begin{tabular}{|c|c|c|c|c|c|c|}
\hline \multirow{3}{*}{ Rocket } & \multicolumn{3}{|c|}{ Quercetin (mg/100 g fw) } & \multirow{2}{*}{\multicolumn{3}{|c|}{$\begin{array}{c}\text { Quercetin }(\mathrm{mg} / 100 \mathrm{~g} \mathrm{fw}) \\
\text { II year }\end{array}$}} \\
\hline & \multicolumn{3}{|c|}{ I year } & & & \\
\hline & S1 & S2 & S3 & S1 & $\mathbf{S 2}$ & S3 \\
\hline Conventional & $3.26 \pm 0.44 c$ & $0.83 \pm 0.57 \mathrm{a}$ & $2.50 \pm 0.43 b$ & $1.89 \pm 1.29 \mathrm{a}$ & $7.74 \pm 2.51 \mathrm{c}$ & $3.31 \pm 0.53 b$ \\
\hline Integrated & $0.68 \pm 1.09 \mathrm{a}$ & $0.50 \pm 0.37 \mathrm{a}$ & $2.65 \pm 0.10 \mathrm{~b}$ & $3.90 \pm 2.52$ & $3.75 \pm 0.74$ & $3.87 \pm 0.10$ \\
\hline$P$ value $\#$ & $* *$ & NS & NS & NS & $* *$ & NS \\
\hline \multirow{3}{*}{ Rocket } & \multicolumn{3}{|c|}{ Lutein $(\mu \mathrm{g} / \mathrm{g}$ fw) } & \multicolumn{3}{|c|}{ Lutein $(\mu \mathrm{g} / \mathrm{g}$ fw) } \\
\hline & \multicolumn{3}{|c|}{ I year } & \multicolumn{3}{|c|}{ II year } \\
\hline & S1 & $\mathbf{S 2}$ & S3 & S1 & $\mathbf{S 2}$ & S3 \\
\hline Conventional & $46.53 \pm 9.3$ & $54.48 \pm 19.7$ & $51.45 \pm 12.1$ & $45.53 \pm 8.4$ & $52.48 \pm 18.6$ & $50.45 \pm 10.2$ \\
\hline Integrated & $44.5 \pm 19.8$ & $51.82 \pm 11.3$ & $41.92 \pm 6.15$ & $42.5 \pm 10.8$ & $51.82 \pm 10.7$ & $40.92 \pm 5.30$ \\
\hline$P$ value $\#$ & NS & NS & NS & NS & NS & NS \\
\hline \multirow{3}{*}{ Rocket } & \multicolumn{3}{|c|}{ Vitamin $C(\mathrm{mg} / 100 \mathrm{~g} \mathrm{fw})$} & \multicolumn{3}{|c|}{ Vitamin $C(\mathrm{mg} / 100 \mathrm{~g} f w)$} \\
\hline & \multicolumn{3}{|c|}{ I year } & \multicolumn{3}{|c|}{ II year } \\
\hline & S1 & $\mathbf{S 2}$ & S3 & S1 & $\mathbf{S 2}$ & $\mathbf{S 3}$ \\
\hline Conventional & $81.74 \pm 6.32 b$ & $53.78 \pm 4.40 \mathrm{a}$ & $57.02 \pm 4.22 \mathrm{a}$ & $27.59 \pm 1.57 b$ & $20.78 \pm 0.21 \mathrm{a}$ & $34.15 \pm 0.19 c$ \\
\hline Integrated & $73.56 \pm 0.51 \mathrm{a}$ & $76.18 \pm 0.00 \mathrm{~b}$ & $80.98 \pm 10.75 b$ & $29.46 \pm 1.08 \mathrm{a}$ & $37.25 \pm 1.40 \mathrm{~b}$ & $41.11 \pm 0.74 c$ \\
\hline$P$ value ${ }^{\#}$ & NS & $*$ & $*$ & NS & $* * *$ & $* * *$ \\
\hline
\end{tabular}

The phenolic composition of Brassica vegetables has been recently investigated [17]. As shown in Table 1, quercetin content in rocket varies within $0.50 \pm 0.37 \mathrm{mg} / 100 \mathrm{~g}$ fw and $7.74 \pm 2.51 \mathrm{mg} / 100 \mathrm{~g}$ fw; these results are consistent with data reported in the literature [3,18]. Bennet et al. [3], studying cruciferous species (Eruca sativa, Diplotaxis erucoides, Diplotaxis tenuifolia and Bunias orientalis), observed that all rocket tissues, except roots, contained significant levels of polyglycosilated flavonoids.

Weckerle et al. [19] identified three glucopyranosides of quercetin in Eruca Sativa leaves using NMR techniques. In a study by Martínez-Sánchez et al. [20], important differences between flavonoid profiles of E. vesicaria and D. tenuifolia were observed: E. vesicaria contained kaempferol derivatives as principal compounds, whereas $D$. tenuifolia accumulated quercetin derivatives.

Leafy vegetables contain several types of photosynthetic pigments, such as chlorophylls and carotenoids [21,22]. Znidarcic et al. [23], studying pigments content of leafy vegetables (chicory, 
dandelion, garden rocket and wild rocket) commonly consumed in Mediterranean area, have shown that leafy vegetables are almost the richest dietary sources of lutein among xanthophyll pigments.

In our research, the rocket lutein content ranged from $40.92 \pm 5.30 \mu \mathrm{g} / \mathrm{g}$ fw to $54.48 \pm 19.17 \mu \mathrm{g} / \mathrm{g}$ fw. No significant differences were detected between conventional and integrated rockets and between the first and second year of cultivation for both agronomic practices (Table 1).

Martínez-Sánchez et al. [18] found a high vitamin C content in rocket. As reported in Table 1, in both years of cultivation, the content of vitamin $\mathrm{C}$ was significantly higher in the integrated product compared with the conventional product (I year: $P<0.05$; II year: $P<0.001$ ), except for the first sampling of both years of cultivation.

A correlation between antioxidant properties and components such as phenolics, carotenoids and vitamin $\mathrm{C}$ has been reported [18,24]. The determination of antioxidant properties could be envisaged as the first stage in studying the potential benefits of foods.

Table 2 shows FRAP (Ferric Reducing Antioxidant Power) values (mmol/Kg fw) of rocket distributed by agronomic practice and year of cultivation. Among the cruciferous vegetables, rocket represents a good source of antioxidants [25]. In addition, several works showed that the antioxidant properties depend on the species, agronomic practices and storage [4,18,26]. Heimler et al. [4], by comparing the antiradical activity (determined by the reaction with the DPPH radical) of Lactuca sativa, Cicorium intybus, Plantago coronopus, Eruca sativa, Diplotaxis tenuifolia, have shown that Eruca sativa and Diplotaxis tenuifolia are the least antioxidant salads among those tested.

Table 2. FRAP values of rocket distributed by agronomic practice and year of cultivation $\Omega$.

\begin{tabular}{|c|c|c|c|c|c|c|}
\hline \multirow[t]{2}{*}{ Rocket } & \multicolumn{3}{|c|}{ FRAP (mmol/kg fw) } & \multicolumn{3}{|c|}{$\begin{array}{c}\text { FRAP }(\mathrm{mmol} / \mathrm{kg} \mathrm{fw}) \\
\text { II year }\end{array}$} \\
\hline & S1 & $\mathbf{S 2}$ & S3 & S1 & S2 & S3 \\
\hline Conventional & $4.44 \pm 0.11 \mathrm{a}$ & $6.93 \pm 0.22 b$ & $7.90 \pm 0.24 c$ & $7.76 \pm 0.69 b$ & $9.92 \pm 0.46 c$ & $7.27 \pm 0.17 \mathrm{a}$ \\
\hline Integrated & $4.13 \pm 0.17 a$ & $7.22 \pm 0.34 b$ & $7.67 \pm 0.27 b$ & $8.56 \pm 0.70 \mathrm{~b}$ & $11.02 \pm 0.45 c$ & $7.31 \pm 0.26 \mathrm{a}$ \\
\hline$P$ value $\#$ & NS & $* *$ & NS & NS & $*$ & NS \\
\hline
\end{tabular}

FRAP values do not differ between conventional and integrated rocket, with the exception of the second sampling of both the first and the second year of cultivation where it was observed to be higher in integrated samples than in conventional samples.

In addition, FRAP values vary with respect to the times of harvest. In the first year of cultivation both agronomic practices exhibited FRAP values $(\mathrm{mmol} / \mathrm{Kg}$ fw $)$ that were lowest $(P<0.001)$ in wild rocket cultivated in June. In contrast, in the second year of cultivation, the products cultivated in September reached the lowest values. 


\subsection{Cytotoxicity and Antiproliferative Activity of Rocket Polyphenol Extract}

The cytotoxicity and antiproliferative activity of rocket polyphenol extract were studied using human colon carcinoma (Caco-2) cells. The cytotoxic effect of the polyphenol rocket extract was evaluated measuring cell viability by the MTT test. Figure 1 shows cytotoxicity obtained using Caco-2 cell model and expressed as cell viability percentage: $0.5,1,5,10 \mathrm{~mL} / \mathrm{L}$ rocket polyphenol concentrations did not affect cell viability, while 50 and $100 \mathrm{~mL} / \mathrm{L}$ rocket polyphenol extract concentrations reduced cell viability to values between $31 \%$ and $71 \%$ and from $6 \%$ to $29 \%$ respectively. The same behavior was observed for conventional and integrated extracts; in addition, for both conventional and integrated products, no differences were observed with respect to times of harvest, except for the second sampling of integrated rocket.

Figure 1. Effect of polyphenol rocket extract on Caco-2 cell viability *.

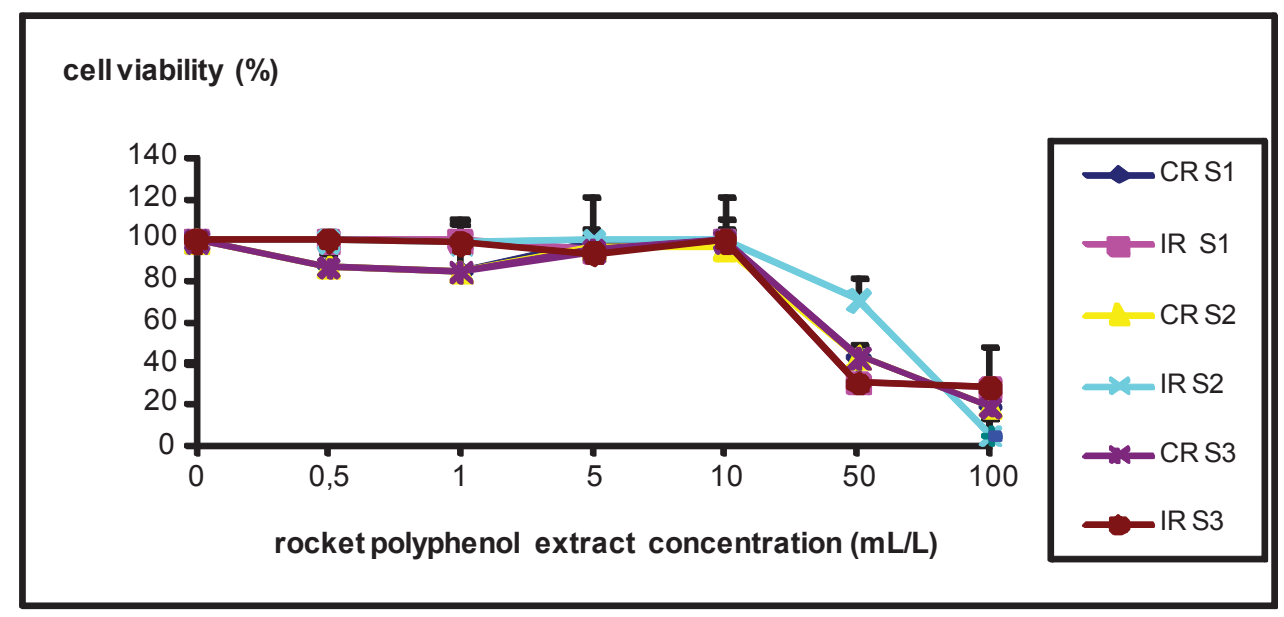

* $\mathrm{CR}=$ conventional rocket; IR = integrated rocket; S1-S2-S3 = Samplings1-2-3.

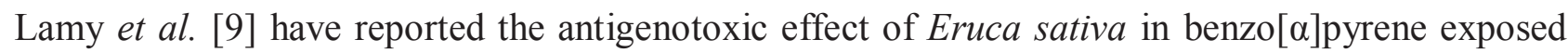
human hepatoma (HepG2) cells. Recently, Jin et al. [27] have studied the expression of genes involved in glucosinolate metabolism and antigenotoxicity of rocket leaf glucosinolates extract: glucosinolate-rich extracts of Eruca sativa cv. Sky, but not Diplotaxis tenufolia cv. Voyager, confer significant resistance of oxidative stress. Melchini et al. [28] demonstrated anti-proliferative activity on human lung carcinoma A545 cells of erucin from rocket salads.

We investigated the effect of the rocket polyphenol extract on cell proliferation; the distribution of cells in each phase of the cell cycle was determined by flow cytometric analysis of DNA content. As reported in Figure 2, a significant accumulation $(P<0.05)$ of cells in G1 phase and a consequent reduction in the $\mathrm{S}$ and $\mathrm{G} 2+\mathrm{M}$ phases were observed in Caco-2 cells treated with $10 \mathrm{~mL} / \mathrm{L}$ rocket polyphenol extract. No difference in biological effect was observed between conventional and integrated samples and between the several times of harvest for both agronomic practices. 
Figure 2. Effect of $10 \mathrm{~mL} / \mathrm{L}$ rocket polyphenol extract on cell cycle ${ }^{\#}$.

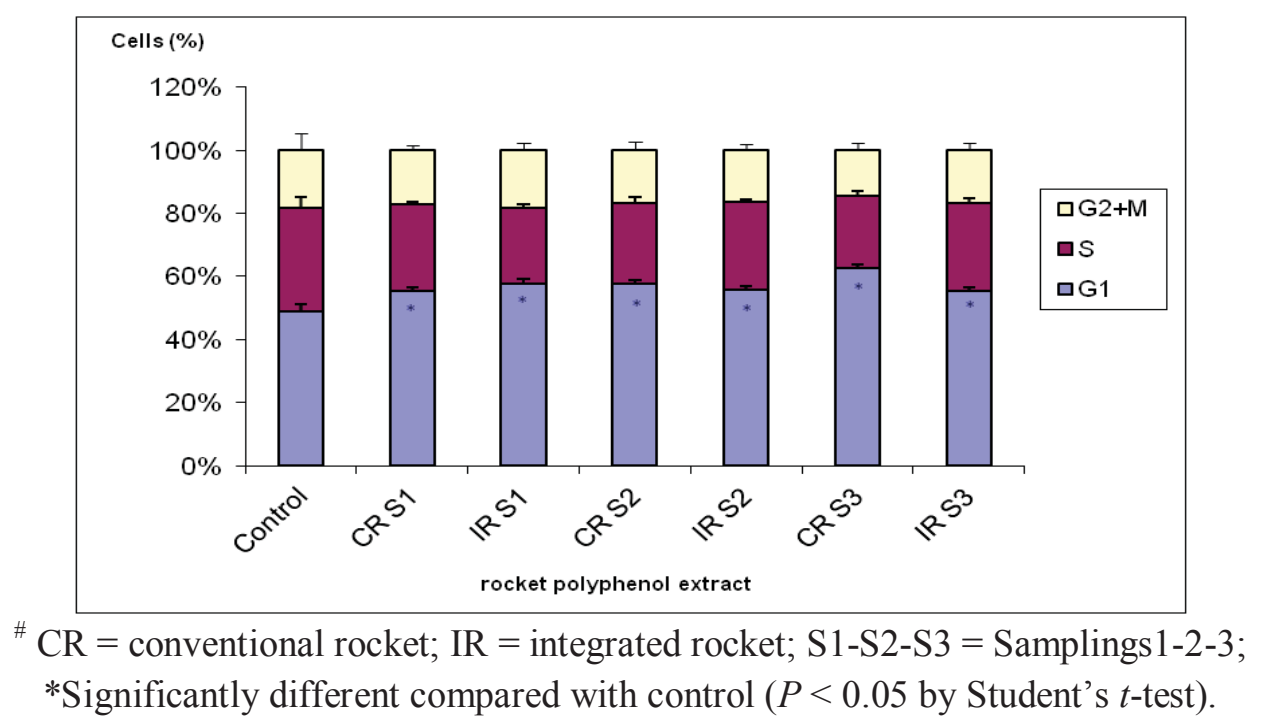

The reduction of the number of cells in the $\mathrm{S}$ phase induced by rocket polyphenol extract was also confirmed by cytometric evaluation of BrdU incorporation. Figure $3 a, b$ shows as example the incorporation of BrdU in control cells and in cells treated with $10 \mathrm{~mL} / \mathrm{L}$ polyphenol extract derived from the first sampling of the first year of cultivation' rocket grown in conventional regime.

Figure 3. (a) incorporation of BrdU in control cells; (b) Incorporation of BrdU in cells treated with $10 \mathrm{~mL} / \mathrm{L}$ polyphenol of CR S1.

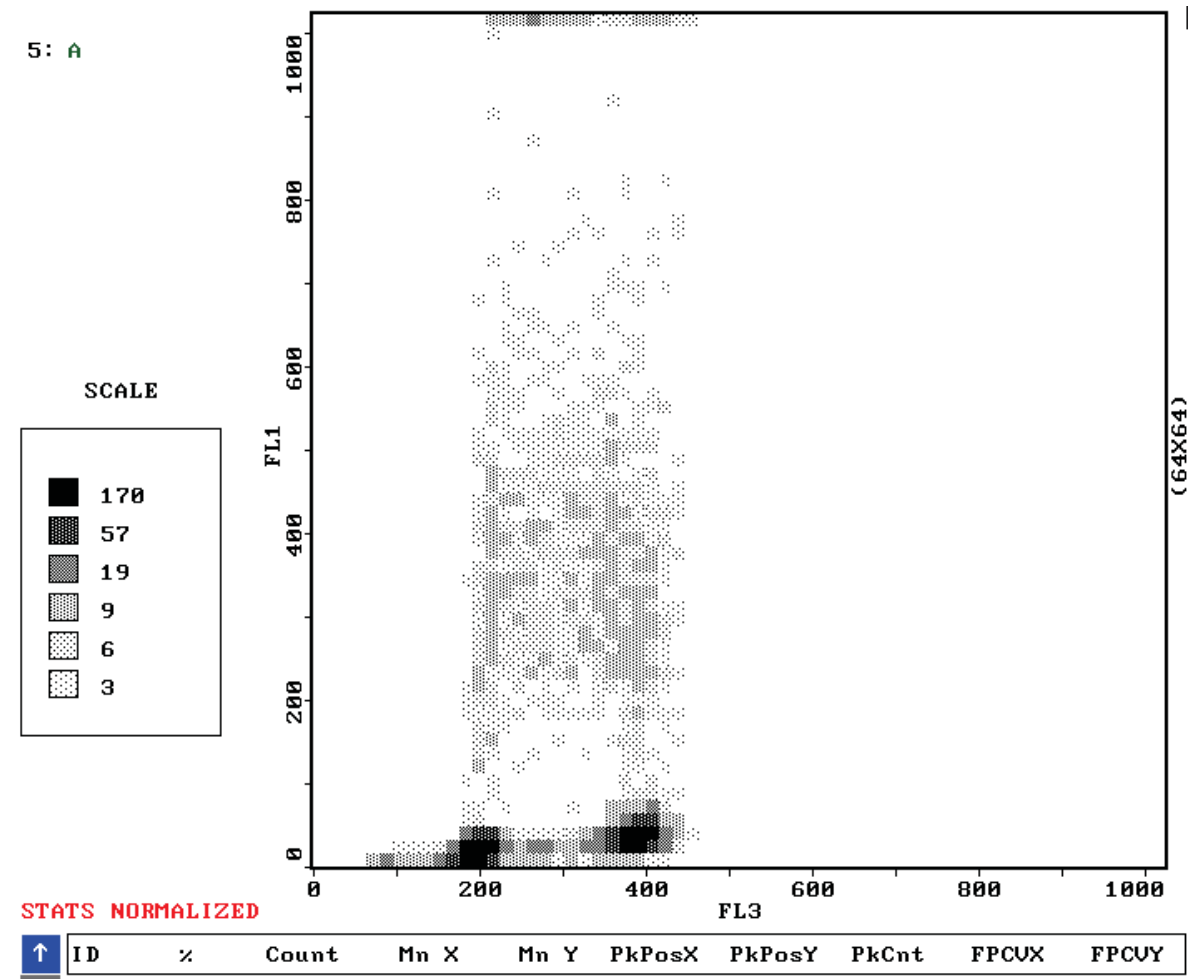

(a) 
Figure 3. Cont.

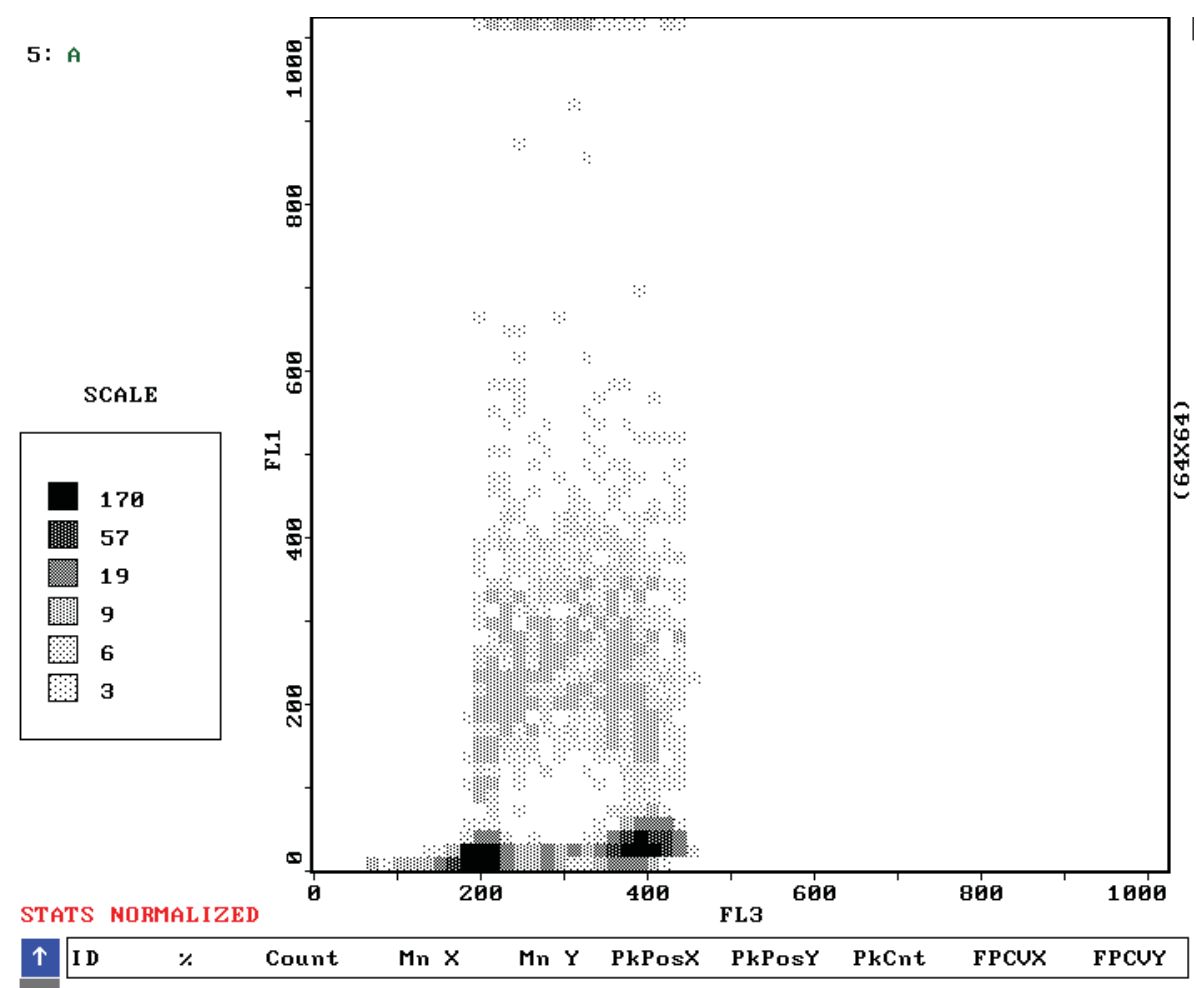

(b)

Cytotoxicity and antigenotoxic properties of the rocket extract could be due to combined or synergistic activities of several bioactive compounds present in the edible part of the plant as shown in the literature for other food extracts $[9,29,30]$.

\section{Experimental Section}

\subsection{Plant Material}

Greenhouse experiments were carried out over a period of two years at two farms, a conventional farm (Fogliamica Orticoltura F.1li Tebaldini) and an integrated farm (Orticoltura Ferrari Elio) located in the same vicinity to ensure similar climatic and soil conditions. Cultivation area was in the province of Brescia, Italy. At both farms, cold greenhouses were used, consisting of metal frames covered in plastic sheeting and having a sprinkler irrigation system. Greenhouse surface areas were $300 \mathrm{~m}^{2}$ for the conventional farm and $500 \mathrm{~m}^{2}$ for the integrated farm. For both farms, soil is calcareous, medium- to fine-textured, slightly alkaline; it has a low carbon-nitrogen ratio and a high Cation Exchange Capacity (CEC).

Fertilization for the integrated practice consisted of manure application at the rate of $70 \mathrm{q} / \mathrm{ha}$ at the beginning of each crop cycle. For the conventional practice, the fertilizer Nitrophoska 20-20-20 was applied at the rate of $17 \mathrm{q} / \mathrm{ha}$ at the beginning of each crop cycle; in addition, for the conventional practice, a fertigation treatment was carried out after each crop cutting.

For conventional practice the pest control consisted of two treatments of Cyfluthrin (Baythroid $5 \mathrm{EC})(0.5 \mathrm{~L} / \mathrm{ha})$ for each crop cycle, whereas for integrated practice a single treatment was conducted by spraying Deltamethrin (Bayer Crop Science) $(2.5 \mathrm{~L} / \mathrm{ha})$ after each crop cycle. 
For the conventional practice soil disinfestation was performed with Basamid once every two years, while for the integrated practice soil disinfestation treatment was not applied.

For each agronomic practice samplings were replicated three times each year. For each year, the first sampling was carried out in June (S1), the second in July (S2) and the third in September (S3). In addition for each sample, as a rule, both conventional and integrated vegetables were harvested on the same day. For each sampling, leaves from 10 plants per cultivar per treatment group were harvested together.

\subsection{Chemicals and Standards}

All the solvents and reagents were of HPLC or Optima grade; common reagents and standards were purchased from Sigma-Aldrich Srl (Milan, Italy), Extrasynthese (Genay, France), Carlo Erba (Milan, Italy) and BDH Laboratory Supplies (Poole, UK) and were of the highest grade available. Double-distilled water (Millipore, Milan, Italy) was used throughout the study.

\subsection{Sample Preparation Method}

The crops were delivered directly to the laboratory and sampled on receipt. Only the edible portion of the samples was utilized for analysis and injured samples were not selected. Fresh samples were homogenized in a Waring blender. The extraction of carotenoids, vitamin $\mathrm{C}$, polyphenols and antioxidant activity were done on the same day. Three replicates were prepared from each sample.

\subsection{Extraction and Quantification of Polyphenols}

Phenolics were hydrolyzed to obtain total free forms and extracted as described by Hertog et al. [31]. Briefly, polyphenols were extracted from about $3 \mathrm{~g}$ homogenized sample with methanol after acidic hydrolysis with $\mathrm{HCl}(6 \mathrm{M})$ at $90{ }^{\circ} \mathrm{C}$ for $2 \mathrm{~h}$. Quantitative analysis was performed using an ESA series (MODEL 580) of HPLC solvent delivery module, an ESA 5600 eight-channel coulometric electrode array detector and an ESA coularray operating software that controls the equipment and performs data processing (ESA, Chemsford, MA, USA). A Supelcosil LC-18 column $(25 \mathrm{~cm} \times 4.6 \mathrm{~cm}, 5 \mu \mathrm{m})$ with a Perisorb Supelguard LC-18 (Supelco, Milan Italy) was used. The volume injected was $30 \mu \mathrm{L}$. Chromatography was performed at $30{ }^{\circ} \mathrm{C}$ and $1 \mathrm{~mL} \mathrm{~min}^{-1}$ flow rate using $0.02 \mathrm{M}$ sodium phosphate adjusted with $85 \%$ ortophosphoric acid to $\mathrm{pH} 2.8$ (solvent $\mathrm{A}$ ) and methanol (solvent $\mathrm{B}$ ). Eluent flow rate was maintained at $1 \mathrm{~mL} \mathrm{~min}^{-1}$ and the setting potentials were set at 60, 120, 200, 340, 480, 620, 760 and $900 \mathrm{mV}[32]$.

\subsection{Extraction and Quantification of Carotenoids}

Carotenoids were determined as described by Sharpless et al. [33]. This method is used by the National Institute of Standards and Technology (NIST, Gaithersburg, Maryland). Briefly, approximately $1 \mathrm{~g}$ of sample was combined with $3 \mathrm{~mL}$ THF (tetrahydrofuran) and $2.7 \mathrm{~mL}$ methanol. The mixture was saponified for $30 \mathrm{~min}$ in a water bath $\left(40{ }^{\circ} \mathrm{C}\right)$ after adding $0.3 \mathrm{~mL}$ of a $40 \%(\mathrm{w} / \mathrm{v})$ methanolic $\mathrm{KOH}$ solution and then $0.15 \mathrm{~g}$ ascorbic acid was added to neutralize the $\mathrm{KOH}$. The analytes were extracted with three $15 \mathrm{~mL}$ portions of hexane-diethyl ether $(50+50)$. The organic phases were combined and 
evaporated under a stream of nitrogen and the residue redissolved in $10 \mathrm{~mL}$ of $\mathrm{n}$-hexane. For the analysis $1 \mathrm{~mL}$ of the sample was re-evaporated and reconstituted in $1 \mathrm{~mL}$ of mobile phase $(50 \%$ methanol, $45 \%$ acetonitrile and $5 \%$ tetrahydrofuran). $50 \mu \mathrm{L}$ of reconstituted extract were injected on a Waters Nova Pack C18 column $(3.9 \mathrm{~mm} \times 150 \mathrm{~mm}, 4 \mu \mathrm{m})$ at a flow rate of $1 \mathrm{~mL} \mathrm{~min}^{-1}$. The extracts were analyzed by a Perkin-Elmer ISS 200 series HPLC system. The eluents were methanol/acetonitrile/ tetrahydrofuran (50:45:5). The peaks were detected with a variable spectrophotometric detector (Perkin-Elmer LC-95, Norwalk, CO, USA) connected to a personal computer Pe Nelson mod 1020 (Perkin-Elmer). The detection wavelength was $450 \mathrm{~nm}$ for carotenoids [34].

\subsection{Extraction and Quantification of Vitamin C}

Total ascorbic acid was extracted and quantified by HPLC system according to the method of Margolis et al. [35], with some modifications [36]. Briefly, $1.5 \mathrm{~g}$ of sample was suspended in $5 \mathrm{~mL}$ water. To the sample was added $1 \mathrm{~mL}$ of $0.5 \mathrm{~mol} \mathrm{~L}^{-1}$ of dibasic potassium phosphate containing $100 \mathrm{~g} \mathrm{~L}^{-1}$ of DTT (1,4-dithiothreitol). The sample was vortexed for $15 \mathrm{~s}$, kept at room temperature for 30 min and $1 \mathrm{~mL}$ of aqueous MPA (400 $\mathrm{g} \mathrm{L}^{-1}$ metaphosphoric acid) was added. After adding $2 \mathrm{~mL}$ of acetonitrile, the suspension was centrifuged $\left(1000 \mathrm{~g}, 30 \mathrm{~min}, 5{ }^{\circ} \mathrm{C}\right)$ and the supernatant was transferred to $1.8-\mathrm{mL}$ vials. Chromatographic separation was carried on a $250 \times 4.6 \mathrm{~mm}$ Capcell $\mathrm{Pak} \mathrm{NH}_{2}$ column (Shiseido, Tokyo, Japan), using ESA series HPLC, equipped an eight-channel coulometric electrode array detector and an ESA CoulArray operating software that controls the equipment and performs data processing (ESA, Chemsford, MA, USA). The setting potential was 0, 100, 200, 300 and $400 \mathrm{mV}$. The column was equilibrated at $40{ }^{\circ} \mathrm{C}$ at a flow rate of $0.8 \mathrm{~mL} \mathrm{~min}^{-1}$ with a solvent composed of $0.680 \mathrm{~g}$ monobasic potassium phosphate, $200 \mathrm{~mL}$ water, $800 \mathrm{~mL}$ acetonitrile and $7.5 \mathrm{~mL}$ concentrated phosphoric acid. The injection volume was $30 \mu \mathrm{L}$.

\subsection{Antioxidant Properties Evaluation}

Antioxidant properties were evaluated using FRAP (Ferric Reducing Antioxidant Power). $1 \mathrm{~g}$ of the homogenized sample was extracted with $4 \mathrm{~mL}$ of water under agitation for $15 \mathrm{~min}$ at room temperature, centrifuged at $1000 \mathrm{~g}$ for $10 \mathrm{~min}$ and the supernatant (water soluble fraction) was collected. The extraction was repeated with $2 \mathrm{~mL}$ of water. The two supernatants were combined and directly used for assay. The residue was extracted using $4 \mathrm{~mL}$ of acetone under agitation for $15 \mathrm{~min}$ at room temperature, centrifuged at $1000 \mathrm{~g}$ for $10 \mathrm{~min}$ and the supernatant (liposoluble fraction) was collected. The extraction was repeated with $2 \mathrm{~mL}$ of acetone. The two supernatants were combined and directly used for assay [37].

Values of samples were obtained by summing the values of water and liposoluble fractions. The method followed Benzie and Strain [38] and Pulido et al. [39] through the use of a Tecan Sunrise ${ }^{\circledR}$ plate reader spectrophotometer. The method is based on the reduction of $\mathrm{Fe}^{3+}-\mathrm{TPTZ}(2,4,6$-tripyridyl-striazine) complex to ferrous at low $\mathrm{pH}$. 


\subsection{Cell Culture}

The human colon adenocarcinoma Caco-2 cells were obtained from European Tissue Culture Collection and cultured in D-MEM with GlutaMAX ${ }^{\mathrm{TM}}$ - I supplemented with $10 \%$ fetal bovine serum and $100 \mathrm{IU} / \mathrm{mL}$ penicillin and $100 \mu \mathrm{g} / \mathrm{mL}$ streptomycin (all from Gibco-Invitrogen). Cells were grown at $37{ }^{\circ} \mathrm{C}$ in a humidified atmosphere containing $5 \% \mathrm{CO}_{2}$. This investigation has been carried out utilizing polyphenol fractions from rocket hydrolyzed extracts derived from the first year of cultivation' rocket grown in conventional and integrated regimes in the three samplings.

\subsection{Cell Viability}

Cells were plated in 24-well tissue culture plates at the concentration of $2 \times 10^{5}$ cells/well and treated for $24 \mathrm{~h}$ with increasing concentrations of conventional and integrated rocket polyphenols extract $(0.5,1$, $5,10,50,100 \mathrm{~mL} / \mathrm{L}$ ); cell viability was determined by the 3-[4,5-dimethylthiazolil-2yl]-2,5-diphenyltetrazoliumbromide (MTT) colorimetric assay [40], as reported previously [41].

\subsection{Antiproliferative Activity}

In order to study the effect of the rocket polyphenol extracts on cell proliferation, we performed a cell cycle distribution analysis by determining bromodeoxyuridine (BrdU) incorporation versus DNA content. Caco-2 cells were incubated with $30 \mu \mathrm{M}$ BrdU during the last hour of a 24-h treatment with $10 \mathrm{~mL} / \mathrm{L}$ rocket polyphenol extracts, fixed in cold 70\% ethanol. Fixed cells were washed in PBS, resuspended in $2 \mathrm{~N} \mathrm{HCl}$ for $30 \mathrm{~min}$ at room temperature, pelleted, and then resuspended in $0.1 \mathrm{~N}$ sodium tetraborate for $15 \mathrm{~min}$. The samples were then washed in PBS, incubated for $15 \mathrm{~min}$ in PBS containing $1 \%$ bovine serum albumin and $0.2 \%$ Tween-20 (PBT), and then for 60 min in $100 \mu \mathrm{L}$ of anti-BrdU monoclonal antibody (Becton Dickinson) diluted 1:20 in PBT. After two washes with PBT, cells were incubated for 30 min with $100 \mu \mathrm{L}$ of FITC-conjugated anti-mouse antibody (Amersham) dilute 1:100 in PBT, then washed twice and resuspended in PBS containing $5 \mu \mathrm{g} / \mathrm{mL}$ Propidium Iodide (PI) and $1 \mathrm{mg} / \mathrm{mL}$ of RNase A. Cells were analyzed with a Coulter Epics XL flow cytometer (Coulter Corporation). Ten thousand cells were measured for each sample. Computer statistical analysis of Mean Fluorescence Intensity (MFI) and graphic representation were performed with the XL2 software (Coulter Corporation) [42].

\subsection{Statistics}

All analyses were performed in triplicate. Data are given as the mean and Standard Deviation (SD). Statistical analysis was performed using Statistica for Windows statistical package (release 4.5; StatSoft Inc., Vigonza PD, Italy).

One-way Analysis of Variance (ANOVA) and a Least Significant Difference (LSD) test at a 95\% confidence level $(p<0.05)$ was used to identify differences between samplings within each year.

$P$-values were calculated to determine the significance of observed differences between conventional and integrated treatments by Student's $t$-test. 
For cytotoxicity and antiproliferative experiments, mean values of the percentage of cells in each phase of cell cycle were obtained from three independent experiments; the significance was calculated in comparison to the control, using the Student's $t$-test.

\section{Conclusions}

Our results confirm as phytochemicals content are strongly dependent by environmental factors and growing factors in wild rocket. This agronomic research have shown that there are significant differences in the quality of rockets of the two cultivation systems compared, while no influence of agronomic practice on biological activity in vitro was reported. Our findings could be useful in the selection of agronomic practices to produce healthful and more nutritious food crops, potentially enhancing the commercial value of this crop.

Results obtained could contribute to a better understanding of the potential health benefits of cruciferous vegetables. The characteristics of wild rocket as a dietary source of antioxidants have been pointed out. The apoptotic and antiproliferative effects of rocket polyphenol extracts could be promising with respect to the potential beneficial activity associated with rocket consumption. The potential protective effect observed in vitro needs to be clarified and verified by in vivo animal model studies as well as pharmacokinetics studies. Thus, future research is needed to assess the biological role of rocket extracts in vivo.

\section{Acknowledgments}

This research was supported by Regione Lombardia Orto-nutritrio project. We thank Ager s.r.l., Custodia s.r.l, Agronomia s.r.l. for their collaboration and their assistance in this research and the farms for the provision of samples.

\section{References}

1. Padulosi, S. Rocket Genetic Resources Network; Report of the First Meeting, Lisbon, Portugal, 13-15 November 1994; International Plant Genetic Resources Institute (IPGRI): Rome, Italy, 1995.

2. De Feo, V.; Senatore, F. Medicinal plants and phytotherapy in the Amalfitan coast, Salerno Province, Campania, Southern Italy. J. Ethnopharmacol. 1993, 39, 39-51.

3. Bennet, R.N.; Rosa, E.A.S.; Mellon, F.A.; Kroon, P.A. Ontogenic profiling of Glucosinolates, Flavonoids and other secondary metabolites in Eruca Sativa (Salad Ricket), Diplotaxis erucoides (Wall Rocket), Diplotaxis tenuifolia (Wild Rocket), and Bunias orientalis (Turkish Rocket). J. Agric. Food Chem. 2006, 54, 4005-4015.

4. Heimler, D.; Isolani, L.; Vignolini, P.; Tombelli, S.; Romani, A. Polyphenol content and antioxidative activity in some species of freshly consumed salads. J. Agric Food Chem. 2007, 55, 1724-1729.

5. D’Antuono, L.F.; Elementi, S.; Neri, R. Glucosinolates in Diplotaxis and Eruca: Diversity, taxonomic relations and applied aspects. Phytochemistry 2008, 69, 187-199. 
6. Pasini, F.; Verardo, V.; Caboni, M.F.; D’Antuono, L.F. Determination of glucosinolates and phenolic compounds in rocket salad by HPLC-DAD-MS: Evaluation of Eruca sativa Mill. and Diplotaxis tenuifolia L. genetic resources. Food Chem. 2012, 133, 1025-1033.

7. Higdon, J.V.; Delage, B.; Williams, D.E.; Dashwood, R.H. Cruciferous vegetables and human cancer risk: Epidemiologic evidence and mechanistic basis. Pharmacol. Res., 1992, 55, 224-236.

8. Lynn, A.; Collins, A.; Fuller, Z.; Hillman, K.; Ratcliffe, B. Cruciferous vegetables and colorectal cancer. P. Nutr. Soc. 2006, 65, 135-144.

9. Lamy, E.; Schroder J.; Paulus, S.; Brenk, P.; Stahl, T.; Mersch-Sundermann, V. Antigenotoxic properties of Eruca sativa (rocket plant), erucin and erysolin in human hepatoma (HepG2) cells towards benzo(a)pyrene and their mode of action. Food Chem. Toxicol. 2008, 46, 2415-2421.

10. Alqasoumi, S.; Al-sohaibani, M.; Al-Howiriny, T.; Al-Yahya, M.; Rafatullah, S. Rocket "Eruca sativa": A salad herb with potential gastric anti-ulcer activity. World. J. Gastroenterol. 2009, 15, 1958-1965.

11. Amarowicz, R.; Carle, R.; Dongowski, G.; Durazzo, A.; Galensa, R.; Kammerer, D.; Maiani, G.; Piskula, M.K. Influence of postharvest processing and storage on the content of phenolic acids and flavonoids in foods. Mol. Nutri. Food Res. 2009, 53, S151-S183.

12. Raigon, M.D.; Rodriguez-Burruezo, A.; Prohens, J. Effects of organic and conventional cultivation methods on composition of eggplant fruits. J. Agric. Food Chem. 2010, 58, 6833-6840.

13. Sansavini, S. Integrated fruit production in Europe: Research and strategies for a sustainable industry. Hort. Sci. 1997, 68, 25-36.

14. Morris C.; Winter, M. Integrated farming systems: the third way for European agriculture? Land Use Policy 1999, 16, 193-205.

15. Hecke, K.; Herbinger, K.; Veberic, R.; Trobec, M.; Toplak, H.; Stampar, F.; Keppel, H.; Grill, D. Sugar-, acid- and phenol contents in apple cultivars from organic and integrated fruit cultivation. Eur. J Clin. Nutr. 2006, 60, 1136-1140.

16. Tarozzi, A.; Hrelia, S.; Angeloni, C.; Morroni, F.; Biagi, P.; Guardigli, M.; Cantelli-Forti, G.; Hrelia, P. Antioxidant effectiveness of organically and non-organically grown red oranges in cell culture systems. Eur. J. Nutr. 2006, 45, 152-158.

17. Cartea, M.E.; Francisco, M.; Soengas, P.; Velasco, P. Phenolic compounds in Brassica vegetables. Molecules 2011, 16, 251-280.

18. Martinez-Sanchez, A.; Gil-Izquierdo, A.; Gil, M.I.; Ferreres, F. A comparative study of flavonoid compounds, vitamin C, and antioxidant properties of baby leaf Brassicaceae species. J. Agric. Food Chem. 2008, 56, 2330-2340.

19. Weckerle, B.; Michel, K.; Balázs, B.; Schreier, P.; Tóth, G. Quercetin 3,3',4'-tri-O-beta-Dglucopyranosides from leaves of Eruca sativa (Mill.). Phytochemistry 2001, 57, 547-551.

20. Martínez-Sanchez, A.; Llorach, R.; Gil, M.I.; Ferreres, F. Identification of new flavonoid glycosides and flavonoid profiles to characterize rocket leafy salads (Eruca vesicaria and Diplotaxis tenuifolia). J. Agric. Food Chem. 2007, 55, 1356-1363.

21. Kimura, M.; Rodriguez-Amaya, D.B. Carotenoid composition of hydroponic leafy vegetables. $J$. Agric. Food Chem. 2003, 51, 2603-2607.

22. Calvo, M.M. Lutein: A valuable ingredient of fruit and vegetables. Crit. Rev. Food Sci. Nutr. 2005, $54,671-696$. 
23. Žnidarčič, D.; Ban, D.; Šircelj, H. Carotenoid and chlorophyll composition of commonly consumed leafy vegetables in Mediterranean countries. Food Chem. 2009, 129, 1164-1168.

24. Dudonné, S.; Vitrac, X.; Coutière, P.; Woillez, M.; Mérillon, J.M. Comparative study of antioxidant properties and total phenolic content of 30 Plant Extracts of industrial interest using DPPH, ABTS, FRAP, SOD, and ORAC Assays. J. Agric. Food Chem. 2009, 57, 1768-1774.

25. Soengas, P.; Sotelo, T.; Velasco P.; Cartea, M.E. Antioxidant properties of Brassica vegetables. Func. Plant Sci. Biotech. Print. 2011, 5, 43-55.

26. Degl'Innocenti, E.; Pardossi, A.; Tattini, M.; Guidi, L. Phenolic compounds and antioxidant power in minimally processed salad. J. Food Biochem. 2008, 32, 642-653.

27. Jin, J.; Koroleva, O.A.; Gibson, T.; Swanston, J.; Magan, J.; Zhang, Y.; Rowland, I.R.; Wagstaff, C. Analysis of phytochemical composition and chemoprotective capacity of rocket (Eruca sativa and Diplotaxis tenuifolia) leafy salad following cultivation in different environments. J. Agric. Food Chem. 2009, 57, 5227-5234.

28. Melchini, A.; Costa, C.; Traka, M.; Miceli, N.; Mithen, R.; De Pasquale, R.; Trovato, A. Erucin, a new promising cancer chemopreventive agent from rocket salads, shows antiproliferative activity on human lung carcinoma A549 cells. Food Chem. Toxicol. 2009, 47, 1430-1436.

29. D’evoli, L.; Tarozzi, A.; Hrelia, P.; Lucarini, M.; Cocchiola, M.; Gabrielli, P.; Franco, F.; Morroni, F.; Cantelli-forti, G.; Lombardi-Boccia, G. Influence of cultivation system on bioactive molecules synthesis in strawberries: spin-off on antioxidant and antiproliferative activity. J. Food Sci. 2010, 75, C94-C99.

30. Im, S.; Yoon, H.; Nam, T.; Heo, H.J.; Lee, C.Y.; Kim, D. Antineurodegenerative effect of phenolic extracts and caffeic acid derivatives in Romaine lettuce on neuron-like PC-12 cells. $J$. Med. Food 2010, 13, 779-784.

31. Hertog, M.G.L.; Hollman, C.H.; Vanema, D.P. Optimization of a qualitative HPLC determination of a potentially anticarcenogenic flavonoids in vegetables and fruits. J. Agric Food Chem. 1992, 40, 1591-1598.

32. Azzini, E.; Intorre, F.; Vitaglione, P.; Napolitano, A.; Foddai, M.S.; Durazzo, A.; Fumagalli, A.; Catasta, G.; Rossi, L.; Venneria, E.; Testa, M.F.; Raguzzini, A.; Palomba, L.; Fogliano, V.; Maiani, G. Absorption of strawberry phytochemicals and antioxidant status changes in humans. $J$. Berry Res. 2010, 1, 81-89.

33. Sharpless, K.A.; Arce-Osuna, M.; Thoma, J.B.; Gill, M.L. Value assignment of retinyl palmitate, tocopherol and carotenoid concentrations in standard reference material 2383 (Baby food composite). J. AOAC Int. 1999, 82, 288-296.

34. Maiani, G.; Pappalardo, G.; Ferro-Luzzi, A.; Raguzzini, A.; Azzini, A.; Guadalaxara, A.; Trifero, M.; Frommel, T.; Mobarhan, S. Accumulation of beta-carotene in normal colorectal mucosa and colonic neoplastic lesions in humans. Nutr. Cancer 1995, 24, $23-31$.

35. Margolis, S.A.; Schapira, R. Liquid chromatographic measurement of L-ascorbic acid e D-ascorbic acid in biological samples. J. Chromatogr. B 1997, 690, 25-33.

36. Serafini, M.; Bugianesi, R.; Salucci, M.; Azzini, E.; Raguzzini, A.; Maiani, G. Effect of acute ingestion of fresh and stored lettuce (Lactuca sativa) on plasma total antioxidant capacity and antioxidant levels in human subjects. Br. J. Nutr. 2002, 88, 615-623. 
37. Pellegrini, N.; Serafini, M.; Colombi, B.; Del Rio, D.; Salvatore, S.; Bianchi, M.; Brighenti, F. Total antioxidant capacity of plant foods, beverages and oils consumed in Italy assessed by three different in vitro assays. J. Nutr. 2003, 133, 2812-2819.

38. Benzie, I.F.F; Strain, J.J. The ferric reducing ability of plasma (FRAP) as a measure of "antioxidant power": The assay. Anal. Biochem. 1996, 239, 70-76.

39. Pulido, R.; Bravo, L.; Saura-Calixto, F. Antioxidant activity of dietary polyphenols as determined by a modified ferric reducing/antioxidant power assay. J. Agric. Food Chem. 2000, 48, 3396-3402.

40. Mosmann, T. Rapid colorimetric assay for cellular growth and survival: Application to proliferation and cytotoxicity assays. J. Immunol. 1983, 65, 55-63.

41. Lazzè, M.C.; Pizzala, R.; Savio,M.; Stivala, L.A.; Prosperi, E.; Bianchi, L. Anthocyanins protect against DNA damage induced by tert-butylhydroperoxide in rat smooth muscle and hepatoma cells. Mutat. Res. 2003, 535, 103-115.

42. Lazzè, M.C.; Savio, M.; Pizzala, R.; Cazzalini, O.; Perucca, P.; Scovassi, A.I.; Stivala, L.A.; Bianchi, L. Anthocyanins induce cell cycle perturbations and apoptosis in different human cell lines. Carcinogenesis 2004, 25, 1427-1433.

(C) 2013 by the authors; licensee MDPI, Basel, Switzerland. This article is an open access article distributed under the terms and conditions of the Creative Commons Attribution license (http://creativecommons.org/licenses/by/3.0/). 